\title{
A SYNOPSIS OF ENVIRONMENTAL HORIZONTAL WELLS AT THE SAVANNAH RIVER SITE
}

by

\author{
M.E. Denham
}

Westinghouse Savannah River Company

Savannah River Site

Aiken, South Carolina 29808

Lombard, K. H.

\section{DISCLAIMER}

This report was prepared as an account of work sponsored by an agency of the United States Government. Neither the United States Government nor any agency thereof, nor any of their employees, makes any warranty, express or implied, or assumes any legal liability or responsibility for the accuracy, completeness, or usefulness of any information, apparatus, product, or process disclosed, or represents that its use would not infringe privately owned rights. Reference herein to any specific commercial product, process, or service by trade name, trademark, manufacturer, or otherwise does not necessarily constitute or imply its endorsement, recommendation, or favoring by the United States Government or any agency thereof. The views and opinions of authors expressed herein do not necessarily state or reflect those of the United States Government or any agency thereof.

A document prepared for OSTI REPORTABLE at N/A from thru.

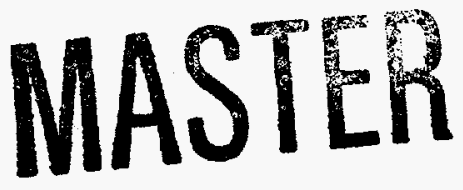

DOE Contract No. DE-AC09-89SR18035

This paper was prepared in connection with work done under the above contract number with the U. S. Department of Energy. By acceptance of this paper, the publisher and/or recipient acknowledges the U. S. Government's right to retain a nonexclusive, royalty-free license in and to any copyright covering this paper, along with the right to reproduce and to authorize others to reproduce all or part of the copyrighted paper. 


\section{DISCLAIMER}

Portions of this document may be illegible in electronic image products. Images are produced from the best available original document. 


\section{DISCLAIMER}

This reporn was prepared as an account of work sponsored by an agency of the United States Government. Neither the United States Governmeat nor any agency thereof, nor any of their employees. makes any warranty, express or implied, or assumes any legal liability or responsibility for the accuracy. completeness, or usefulness of any information, apparatus, product, or process disclosed, or represents that its use would not infringe privately owned rights. Reference berein to any specific commercial produce, process, or service by trade name, trademark, manufacturer, or otherwise does not necessarily constitute or imply its endorsement, recommendation, or favoring by the United States Government or any ageacy thereof. The views and opinions of authors expressed berein do not necessarily state or reflect those of the United States Government or any agency thereof.

This report has been reproduced directly from the best available copy.

Available to DOE and DOE contractors from the Office of Scieatific and Technical Information, P. O. Box 62, Oak Ridge. TN 37831: prices available from (615) $576-8401$.

Available to the public from the National Technical Information Service. U. S. Deparment of Commerce, 5285 Port Royal Rd., Springrield, VA 22161 


\title{
A Synopsis of Environmental Horizontal Wells at the Savannah River Site
}

\author{
by M.E. Denham, Ph.D.and K. H. Lombard, CM
}

\begin{abstract}
Seven horizontal wells for environmental remediation were installed at the Savannah River Site as part of an Integrated Demonstration Project sponsored by the Department of Energy's Office of Technology Development. The wells were used to demonstrate innovative remediation systems for the clean up of chlorinated organic solvent contamination in groundwater and the vadose zone. The wells were installed in four demonstrations of different horizontal drilling technologies. A short-radius petroleum industry technology, a modified petroleum industry technology (using a down-hole motor), a utility industry technology, and a river crossing technology were demonstrated. The goals of the demonstrations were to show the utility of horizontal wells in environmental remediation and further development of the technology required to install these wells.
\end{abstract}

From the first demonstration in 1988 to the latest in 1991, there was significant evolution in horizontal drilling technology. The main technical challenges in the first demonstration were directional control during drilling and borehole instability. Through advancement of the technology these problems were overcome and did not affect the last demonstration. Those considering the use of horizontal wells for environmental remediation will benefit from the knowledge gained from these demonstrations.

\section{Introduction}

Seven horizontal wells were installed at the Savannah River Site (SRS) near Aiken, South Carolina to evaluate and aid in the development of various directional drilling technologies with potential environmental applications. The wells were installed as part of the Integrated Demonstration Project for Cleanup of Organic Contaminants in Soils and Groundwater at Non-arid Sites, sponsored by the Department of Energy's Office of Technology Development. The overall goal of the Integrated Demonstration Program was to demonstrate, at a single location, multiple technologies in the fields of drilling, characterization, monitoring, and remediation. Innovative technologies were compared to one another and to established technologies in terms of technical performance, ease of operation, and cost effectiveness. Transfer of successfully demonstrated technologies to the Department of Energy (DOE) environmental restoration organizations, other government agencies and private industry was a critical part of the program. Installation of the horizontal wells at SRS generated considerable interest among environmental professionals by demonstrating their advantages for in-situ remediation systems.

Horizontal wells offer the environmental industry distinct benefits for many remediation circumstances. They are ideal for remediation of contaminant plumes that have a linear shape such as those that emanate from leaking pipelines or sewers. Horizontal wells can be installed so the axis of the well screen is in the plane of an aquifer. This can substantially increase the contact area of the screen with the aquifer and is ideal for capturing contaminant plumes to prevent their advance. Because of these features horizontal wells can be more efficient than vertical wells in many remediation systems. This was demonstrated at the SRS by the successful operation of an in-situ air stripping system and a bioremediation system for clean up of chlorinated organic solvents. Both systems used a pair of horizontal wells, one for injection and one for extraction. The 
wells proved to be effective delivery systems for stripping agents (air in this case) and nutrients for bioremediation, as well as effective for vacuum extraction. An additional advantage of horizontal wells is that installation may be done from remote locations. This allows remediation of plumes beneath buildings or other structures in which installation of vertical wells would be costly or impossible.

The potential for horizontal wells in the environmental industry was recognized from their use by the petroleum and utility industries. The petroleum industry first experimented with horizontal wells in the 1940s and began to use them routinely in the 1980s. They developed technologies for installing deep horizontal wells in consolidated rock to drill along, rather than through, oil bearing formations. Directional drilling also allowed installation of multiple wells from a single platform. In the 1970 s the utility industry began to develop its own technologies to install cables and pipelines beneath roads, buildings, or natural barriers such as rivers. The environmental industry has integrated and modified these technologies to apply to environmental problems.

The first environmental horizontal wells were installed in 1988 as part of the Integrated Demonstration Project at the SRS. The purpose of these two wells and the five that followed was to demonstrate the application of horizontal drilling to environmental problems and to evaluate various methods of installing such wells. Between 1988 and 1993 four horizontal drilling technologies were evaluated and seven wells installed. The four drilling demonstrations were the short-radius petroleum industry method, a modified petroleum industry method (using a down-hole motor), a utility industry method, and a river crossing method.

The evolution of the technology was apparent throughout these demonstrations. The number and extent of problems with drilling and well installation decreased with each demonstration. The major challenges of the early demonstrations were keeping the bore hole open in unconsolidated sediments, directional control during drilling, and determining the location of the drill bit during drilling. By the final demonstration these were not major problems.

\section{Site Description}

The M Area (3/700 Area), located in the northwestern portion of the SRS, is the site of the metals fabrication facility where fuel targets for the reactors were fabricated. The $M$ Area settling basin was used as a settling basin for metal-rich wastes that contained chlorinated organic solvents such as trichloroethylene (TCE), tetrachloroethylene (PCE), and 1,1,1-trichloroethane. Hydrologic investigations at SRS have shown that M-Area operations resulted in the contamination of groundwater and the vadose zone with these solvents near the M-Area Settling Basin. The contamination at this site resulted from the leakage of waste solvents from the M-Area Settling Basin into the vadose zone with subsequent gravity-driven migration of the contaminants into the groundwater. Additional contamination came from a leaking process sewer that ran from the M-Area facilities to the settling basin. The M-Area Settling Basin is now closed and capped according to Resource Conservation and Recovery Act (RCRA) guidelines. As part of the Record of Decision (ROD), a remedial action program consisting of groundwater pumping from eleven vertical recovery wells, followed by above-ground air-stripping in a central tower, was implemented in 1985 to address groundwater contamination in MArea.

\section{Regional Geologic Setting}


SRS is located in the Atlantic Coastal Plain physiographic province. Within the Atlantic Coastal Plain province, SRS lies on the Aiken Plateau which is bounded by the Savannah and Congaree Rivers (Figure 1). The surface of the Aiken Plateau is dissected by streams and is characterized by broad, interfluvial areas with narrow steep-sided valleys.

The Atlantic Coastal Plain is comprised of a wedge of southeast-dipping unconsolidated and semiconsolidated sediments which increase in thickness from zero at the Fall Line to more than 4,000 feet near the Atlantic Coast. These sediments range from Late Cretaceous (100 million years) to Holocene (present) in age, and extend to the seaward edge of the Continental Shelf. The Atlantic Coastal Plain sediments generally consist of strata of gravel, sand, silt, clay, and limestone, which were deposited in a variety of fluvial, deltaic, and marine depositional environments. The base of the Atlantic Coastal Plain sediments lies unconformably on top of crystalline, metamorphic, and granitic rocks in the northern portion of SRS and on top of Triassic sediments, deposited in a rift basin, in the southern part of SRS.

\section{Technology Demonstrations}

\section{Short Radius Petroleum Technology}

The first horizontal drilling demonstration, in 1988, was to evaluate a short radius petroleum technology. Several private companies were involved in this first horizontal drilling demonstration. Conoco Inc. designed the wells and provided site operations supervision. Eastman Christensen (now Eastman Cherrington) supplied directional drilling tools and expertise. They subcontracted Graves Well Drilling of Jackson, SC to provide technical support (equipment, materials, and labor). Graves retained D\&M Drilling Fluids (Jay, FL) to provide expertise in the use and manipulation of drilling fluids. Sirrine Environmental Consultants (Greenville, SC) provided technical oversight and documentation of the project.

For the short radius technology the curve from vertical to horizontal was built initially by deflecting the drill string off of a device known as a "whipstock". A whipstock is a piece of steel pipe with a portion of one side cut out into which a steel plate is welded at an angle to serve as a deflector of the drill string. The whipstock was placed in concrete in the bottom of a vertical hole drilled to the depth at which the curved section was designed to begin.

The curved section of the bore hole was drilled with the aid of a curved drill guide. The curved drill guide is a flexible assembly with an internal drive shaft covered by a nonrotating shell. The guide was placed between the drill bit and the flexible drill string. Drilling of the curved portion began when the drill bit deflected off of the whipstock (Figure 2). As drilling proceeded the curved drill guide continued to bend to the degree required to change the drilling direction from vertical to horizontal. The internal drive shaft of the drill guide translated the rotational torque from the drill string to the bit. This allowed the drill guide itself to remain stationary and reduced deflection from the intended path. When the curved portion was completed the curved drill guide was removed and replaced with a rigid drill mandrel. The rigid drill mandrel guided the bit in a straight path to drill the horizontal section of the bore hole. From this point on there was little directional control during drilling.

For the short-radius technology demonstration the position of the borehole was located with single and multi-shot magnetic surveys that recorded the inclination and azimuth of the hole. A multi-shot survey was done after completion of the curved portion and single 
shot surveys were done at regular intervals during the drilling of the horizontal portion of the borehole. When drilling was finished, a multi-shot survey was conducted of the entire borehole. This proved to be an accurate method of locating the borehole, but required that drilling stop during the survey. This was cumbersome and increased the chance of borehole collapse.

Two wells that were designed for use by injection-recovery systems were installed using the short radius technology. The design placed the horizontal portion of the injection well below the water table (target depth 151-157 feet [46-48 m] below surface). The recovery well was designed to have the horizontal portion in the vadose zone, oriented so that it was in same plane as the injection well but about 90 feet $(27 \mathrm{~m})$ above (target depth of $65-75$ feet $[20-23 \mathrm{~m}]$ below surface).

Drilling of the injection well borehole was relatively free from problems. There was evidence of borehole instability during drilling. However, the main problem was that the bit tended to drift downward during drilling of the horizontal portion. After several attempts this was corrected and the final total vertical depth of the borehole was 176 feet $(54 \mathrm{~m})$. After drilling was completed the borehole was enlarged, to facilitate screen installation, by reaming with a special $7-7 / 8$ inch $(20 \mathrm{~cm})$ wing bit. During the final survey of the borehole the drill string became stuck. Several attempts to remove it failed and the final attempt broke the drill string just below the curved portion of the hole. Despite the break, the well was completed. The borehole was flushed using drilling fluid pumped through steel tubing lowered down the hole. This allowed installation of a 2-3/8 inch $(6 \mathrm{~cm})$ perforated steel tubing to be used as screen for the injection well. The final total measured length of the screen and casing was 460 feet $(140 \mathrm{~m})$.

Drilling and installation of the upper recovery well encountered additional problems, but was ultimately successful. Some of the difficulties resulted from experimentation with new techniques, but much was learned from this experimentation. During the five attempts required to successfully complete the borehole, the major problems encountered were borehole instability and movement of the curved drill guide during drilling. In addition, the well materials in the original design $(5-1 / 2$ inch $[14 \mathrm{~cm}]$ diameter) were found to be more rigid than is optimal to negotiate the curved section. The problem was solved by replacing the original casing with more flexible $4-1 / 2$ inch $(11.4 \mathrm{~cm})$ diameter casing. The final borehole was completed to a total measured depth of 283 feet $(86 \mathrm{~m})$ and a final vertical depth of 78.5 feet $(23.9 \mathrm{~m})$ below surface. After borehole completion, 204.7 feet $(62.4 \mathrm{~m})$ of $4-1 / 2$ inch $(11.4 \mathrm{~cm})$ diameter stainless steel wire-wrapped screen with 0.010 inch slots was installed.

Final well development was by flushing with fresh water and a solution of sodium hexametaphosphate to disperse filter cake built up on the walls of the borehole. This increases permeability around the screen and promotes greater efficiency in the injection and recovery process.

Because of the experimental nature of this project, changes in the drilling program were made in the field in response to problems. The main change in the drilling program was elimination of the reaming step prior to screen installation. The benefits of borehole enlargement were negated by the decrease in borehole stability caused by the reaming. It was learned that lower penetration and bit rotation rates lowered the chance of borehole collapse and caused less stress to the equipment. In addition, a better understanding was gained of the effect of geologic conditions on horizontal drilling.

The minimal radius of curvature is the advantage of the short radius technology, but some disadvantages were recognized as well. The short radius of curvature allows conversion 
from vertical to horizontal drilling over a minimal horizontal distance. However, the short radius technology, as implemented in 1988 , allowed only poor directional control during drilling and required that the drill string be removed from the bore hole whenever an adjustment was made. The frequent tripping in and out of the hole reduced the stability of the borehole. Newer drilling technology that was used in later demonstrations could be coupled with the short radius technology to allow better directional control and less frequent tripping in and out of the borehole.

\section{Modified Petroleum Technology}

After the initial demonstration Eastman-Christensen Environmental Services developed a new drilling system for environmental well installations. Thus, Eastman-Christensen was retained as the drilling contractor for the second demonstration. SEC Donohue (Aiken, $\mathrm{SC})$ provided technical oversight and documentation for the project.

The second horizontal drilling demonstration evaluated a modified petroleum technology that used a steerable mud motor. The mud motor (Figure 3 ) could be set at the surface to achieve different radii of curvature. The drill bit was connected to a turbine through which drilling fluid was pumped. This applied torque to the drill bit without rotating the drill string. This was an important advancement because it allowed much better directional control and decreased stress on the drill pipe and the borehole by eliminating the need to continually rotate the drill string.

The boreholes were drilled in three sections, a straight slanted portion, a curved portion, and the horizontal portion. The drill rig used was capable of drilling at a slant angle (an angle less than vertical to the surface) and drilled the first portion of the borehole straight, but angled toward the kick-off point of the curved portion. The advantage of this was that it reduced the length of the curved portion, allowing a gentler curve through which to move the drill string and well materials. The angled portion was augered and was followed by the curved and horizontal sections, drilled with the steerable mud motor. Prior to drilling the curved section the eccentric stabilizers in the mud motor were set to achieve a radius of curvature of 110 feet $(33.5 \mathrm{~m})$. After drilling the curved portion, the horizontal section was drilled in a series of opposing arcs that ultimately defined a horizontal path. This allowed the drilling tool to maintain a curve building angle so that any deflections from the designed path could be corrected by changing the orientation of the tool so that it drilled back towards the correct path.

This method of drilling required a more sophisticated survey tool than used in the first demonstration. The survey tool, known as a tool face indicator (TFI), measured the orientation of tool relative to the casing and the inclination of the drill bit. This information was relayed to a computer at the surface by electronic pulses conducted by the drilling fluid. To verify the TFI readings, periodic single-shot surveys were taken. After completion of the curved portion, a multi-shot survey was taken. Upon completion of the horizontal section, the entire borehole was surveyed by a multi-shot survey tool.

The technology was designed to allow installation of the well materials as drilling progressed. The casing could be attached directly behind the drilling tool with the drill string running inside the casing. The drill bit had expandable wings that, when employed, reamed the hole to a sufficient diameter for the casing and screen to pass. Upon completion of the drilling, the wings were retracted and the drilling tool pulled back through the casing. This method has the advantage that long sections of borehole do not have to remain stable throughout the drilling and well installation. However, there were instances when drilling fluid circulation was lost and the well materials became stuck in 
the borehole. If they could not be freed, the hole was abandoned and the well materials lost.

The two wells installed with the modified petroleum technology had a similar design to the wells installed in the first demonstration. An injection well was designed with the horizontal portion below the water table and a recovery well was designed to be in the same plane but in the vadose zone. The vadose zone well was installed first to assess the effects of fluid circulation in the unsaturated sediments. During this installation the major problem encountered was lodging of well materials in the borehole because of borehole instability. However, directional control was significantly improved over the first demonstration. The lessons learned during installation of the vadose zone recovery well were applied to installation of the lower injection well and it was successfully installed in one attempt.

\section{Utility Industry Technology}

The third horizontal drilling demonstration evaluated a utility industry technology to drill a shallow horizontal well. This demonstration was made possible by a Cooperative Research and Development Agreement (CRADA) between Charles Machine Works and Sandia National Laboratory. Camp, Dresser, and McKee (CDM) Federal Programs was subcontracted to provide technical oversight and documentation of the drilling demonstration.

The rig developed by Charles Machine Works (Ditch Witch ${ }^{\circledR}$ ) was a slant rig that operated on a compaction principle. The drill bit was wedge shaped and when advanced created the borehole by compacting sediments to the side of the bit, rather than abrading the sediments. The tendency of the bit to deflect away from the wedged face as the tool was pushed was used to steer the bit. A curve could be built by controlling the orientation of the wedged face. When drilling a straight path with no deflection required, the drill string was rotated so that there was no net deflection of the bit. Anchors set into the ground were used to brace the drill rig against the pushing of the drill string.

Directional control was maintained by continuous monitoring of the drill bit orientation, azimuth, and inclination. This was done with a downhole survey tool that was located directly behind the drill bit. The tool measured rotation of the drill string in $5^{\circ}$ increments, measured the azimuth with a magnetometer and the inclination with an accelerometer. With measurements of azimuth, inclination, and the length of drill string in the borehole, the location of the drill bit in the subsurface could be located. The tool was connected to the drill rig by a conventional wire line, so that readings could be taken while drilling. The survey tool was supplied by Sandia National Laboratory and is available commercially as the Drill Scout ${ }^{\mathrm{TM}}$ from Survey Technology of Santa Ana, California.

One of the advantages of the utility industry technology was that it did not require large amounts of drilling fluid. By compacting cuttings into the wall of the borehole there was no need of a mechanism to remove them. However, during the first attempt at well installation it was found that some water was required lubricate the bit and cool the survey tool.

The well was designed to have an entrance and an exit hole at the surface. The entrance curve was to be drilled to a depth of 35 feet $(10.7 \mathrm{~m})$ below surface, followed by a 230 foot $(70 \mathrm{~m})$ horizontal section, and finished with a curved section that would exit at the surface. The horizontal section was to be placed in a clay layer in which volatile organic contaminants were concentrated. When drilling was completed the casing was to be 
pulled by the drill string from the exit hole back to the entrance. To do this a conical "hole opener" was attached between the drill string and the well casing. As the whole package was pulled back through the borehole, the hole opener ensured that the borehole was of sufficient diameter to install the casing. The well materials in the design were PVC entry and exit risers attached to Teflon slotted pipe in the horizontal section.

Three attempts were required to successfully install the horizontal well. The necessity for three attempts was caused by the failure of the well materials rather than problems with the drilling technology. For each attempt a satisfactory borehole was completed, though minor problems were encountered. During the first attempt the main drilling problem was friction during pushing. This made drilling very difficult and the heat generated rendered the survey tool inoperable. A jet of water pumped through the drill bit during drilling alleviated this problem by lubricating the bit and cooling the survey tool. An additional problem was that the anchors pulled out of the ground under the stress of pushing. On the third attempt the drill rig was placed in a $16 \times 16$ foot $(5 \times 5 \mathrm{~m})$ pit that was 4.5 feet $(1.4$ $\mathrm{m}$ ) deep. The rig was braced against the back of the pit during pushing, providing greater stability than the in-ground anchors.

The initial well materials were too weak to withstand the stress of being pulled through the borehole. Joints of the Teflon and PVC pipe broke during the first two installation attempts. The boreholes in the first two attempts had to be abandoned because they contained irretrievable well materials. The well was finally completed with fiberglass casing and screen, that proved to be stronger than the PVC and Teflon materials. The well was completed with 150 feet $(45.7 \mathrm{~m})$ of 3.5 inch $(8.9 \mathrm{~cm})$ OD fiberglass as the entry riser, 137 feet $(41.8 \mathrm{~m})$ of the same material as the exit riser, and $300(91.4 \mathrm{~m})$ feet of 3.5 inch $(8.9 \mathrm{~cm})$ OD 0.010 slotted fiberglass screen.

Fewer problems were encountered during this technology demonstration than in the first two. Some of the success may be attributable to the geologic conditions. The clay layer in which the horizontal section was emplaced may have been inherently more stable than the sands in which other wells were emplaced. But much of the success is attributable to the technology. The compaction of cuttings into the borehole wall stabilized the borehole against collapse. Subsequent tests indicated that the compaction did not significantly impede flow to the well. The well installation method also prevented problems derived from borehole collapse, because there was always either drill string or well materials in the borehole during drilling and installation. An additional advantage of this technology is that no drilling derived wastes were produced. The relatively small amount of water pumped into the borehole was absorbed by the formation and no cuttings return to the surface. This is a significant advantage when drilling into contamination. The main disadvantage of the utility industry technology is that it can only function at relatively shallow depths in unconsolidated sediments.

\section{River Crossing Technology}

The fourth horizontal drilling demonstration evaluated a river crossing technology. This technology was designed by the utility industry to install cables and pipelines beneath rivers. However, it incorporates petroleum technology into a robust system capable of drilling in a variety of geologic conditions.

Several companies were involved in this demonstration to install two wells in the vadose zone beneath the site of a former seepage basin. EVI Cherrington Environmental Corporation (now Eastman-Cherrington) designed the wells and was the main drilling subcontractor. Sharewell Inc. was subcontracted to provide the directional survey 
equipment and personnel to operate this equipment. Environmental Monitoring and Testing Corporation (EMTC) of New Ellenton, SC was retained to provide a certified South Carolina driller and equipment as necessary. CDM Federal Programs was subcontracted to provide technical oversight and documentation of the demonstration.

The wells were designed as part of a vacuum extraction system to remove volatile solvents from beneath the seepage basin. The design called for two wells to be installed 100 feet $(30.5 \mathrm{~m})$ apart, with parallel paths having horizontal sections 430 feet $(131 \mathrm{~m})$ long at a depth of 90 feet $(27.4 \mathrm{~m})$ below surface. This would place the horizontal portions approximately 10 to 15 feet $(3$ to $5 \mathrm{~m}$ ) above the water table, a depth at which maximum benefit of vacuum extraction would be achieved. The radius of curvature was originally designed to be 300 feet $(91.4 \mathrm{~m})$, but was changed to 400 feet $(121.9 \mathrm{~m})$ after the initial drilling attempt failed.

The river crossing technology incorporated many of the best aspects of other earlier technologies. A slant drill rig was used to decrease the length of curve required to reach a horizontal orientation. Borehole stability was maintained by alternately drilling a section of a pilot hole followed by installation of temporary steel casing over the pilot string. By proceeding in this "leapfrog" fashion the problem of borehole instability was negated. When drilling was complete, the pilot string was removed and the washover pipe was left to provide a conduit for easy installation of well materials. When the well materials were installed the washover pipe was removed.

The drill bit used in this demonstration advanced by abrading the formation with a high pressure jet of drilling fluid. The jet nozzle was at an angle of $2^{\circ}$ from the axis of the pilot string to provide directional control. When not rotating, the bit would advance along a curved path in the direction of the nozzle. To maintain a straight path the bit was rotated, eliminating the preferred orientation of the nozzle. This drill bit generally performed well in the unconsolidated sediments of the Savannah River Site, but would not be useful in consolidated formations or gravels. However, a steerable mud motor can be used in place of the hydro jet bit to overcome difficult drilling conditions.

The drilling fluid used to operate the drill bit and remove cuttings from the borehole was a guar gum suspension. The advantage of this fluid is that it is biodegradable so that fluid lost to the formation presents no contamination or formation damage problems. However, this fluid is less efficient at removing cuttings from the borehole, which may have contributed to problems with drill pipe becoming stuck in the borehole.

The magnetic survey tool used in this demonstration was the most effective of the survey systems used in the four demonstrations. It provided real time information on borehole location through a wire line to the surface and an on-line computer. From measurements of the azimuth and inclination of the bit and length of drill string in the borehole the driller was able to accurately locate the drill bit in the subsurface. Measurements of the drill bit orientation, provided by the survey tool, were used to steer the bit in the proper direction.

The major problem encountered during drilling was washover pipe becoming stuck and breaking in the borehole. In part, this was due to loss of drilling fluid to the formation and the inefficiency of the fluid at removing cuttings. It was also found that the washover pipe used for this demonstration was not of the required strength. Pipe joints were weakened by the oblique stresses experienced during drilling and ultimately broke 4 times. Washover pipe below the breaks was successfully removed after 2 of the pipe failures, but a total of 610 feet $(186 \mathrm{~m})$ of pipe was abandoned in the ground. 
Two wells were successfully installed using the river crossing technology, though the final installation of one differed somewhat from the design. This well was completed through 400 feet $(121.9 \mathrm{~m})$ of abandoned washover pipe to salvage the available borehole. The length of screen installed was 400 feet $(121.9 \mathrm{~m})$, but about 160 feet $(49 \mathrm{~m})$ of this is occluded by the abandoned washover pipe. It was decided that this well could still function adequately with the shortened screen length. In addition, the wells were designed to be 100 feet $(30.5 \mathrm{~m})$ apart, but one was moved 20 feet $(6 \mathrm{~m})$ closer to the other after the initial attempt to drill this well failed.

\section{Summary and Recommendations}

Four demonstrations of horizontal drilling technologies were conducted at the Savannah River Site as part of the Integrated Demonstration Project sponsored by the Department of Energy Office of Technology Development. The purpose of these demonstrations was to evaluate and aid in the development of different horizontal drilling technologies, and to provide horizontal wells from which to stage demonstrations of innovative remediation systems. The demonstrations successfully achieved these objectives.

Technology development was evidenced by the evolution of the technologies from the first demonstration in 1989 to the final demonstration in 1992. Drilling in the first demonstration experienced significant problems with directional control and borehole instability. By the final demonstration in 1992 accurate and reliable survey tools, steerable drill bits, and methods to overcome borehole instability had evolved to a point where these were not major problems.

As shown in Table 1, the four demonstrations also highlighted the advantages, disadvantages, and suitable drilling conditions for each drilling system. The continually expanding market for environmental horizontal drilling ensures that these technologies will continue to evolve.

For those considering horizontal wells for environmental remediation a set of general recommendations are as follows:

- A thorough description of the target zone and surrounding geology should be made available to the well designers and drilling contractors.

- A thorough description of well completion requirements such as screen size, filter pack size (if needed), and specifications of the well string material should be made available to the well designers and drilling contractors.

- From these descriptions the well designers should prepare a detailed plan for the borehole that includes locations the of entry hole and exit hole (if needed), the depth and orientation of the horizontal section, and the radius of curvature required to correctly install the well.

- The drilling contractor should produce a detailed drilling plan that includes the tools necessary to complete the borehole, an analysis of stresses that will be experienced by drilling pipe and well materials during drilling and installation, and recommendations of proper materials to use.

- There should be good communication between the well designers and the drilling contractor so that changes in the well design can be made if necessary. Thus, the drilling contractor should be procured as early in the design process as possible. 
- At the drilling site, well materials should be carefully inspected to ensure they are of appropriate quality to withstand the stresses of installation.

This paper is a synopsis of five reports, produced for the Westinghouse Savannah River Company, that relate to the horizontal drilling demonstrations at SRS. There are detailed accounts of each demonstration and a report summarizing the demonstrations. For further information contact Miles Denham (803-725-5521) or Ken Lombard (803-725-6390) at Westinghouse Savannah River Company, Savannah River Site, Aiken, SC 29808. The five reports are:

Kaback, D.S., B.B. Looney, J.C. Corey, and L.M. Wright, August 1989 Well Completion Report on Installation of Horizontal Wells for In-Situ Remediation Tests, WSRC-RP-89784, Westinghouse Savannah River Company, Savannah River Site, Aiken, SC 29808.

WSRC, December 1992, Demonstration of Eastman Christensen Horizontal Drilling System Integrated Demonstration Site Savannah River Site WSRC-TR-92-577, Westinghouse Savannah River Company, Savannah River Site, Aiken, SC 29808.

WSRC, December 1992, Demonstration of A Utility Industry Horizontal Drilling System: Horizontal Well AMH-5 Installation Report WSRC-TR-93-008, Westinghouse Savannah River Company, Savannah River Site, Aiken, SC 29808.

WSRC, May 1993, Demonstration of River Crossing Technology for Installation of Environmental Horizontal Wells: AMH-6 and AMH-7 Installation Report WSRC-TR-93387, Westinghouse Savannah River Company, Savannah River Site, Aiken, SC 29808.

WSRC, October 1993, Summary Report of the Drilling Technologies Tested at the Integrated Demonstrations Project for Cleanup of Organic Contaminants in Soils and Groundwater at Non-arid Sites WSRC-TR-93-565, Westinghouse Savannah River Company, Savannah River Site, Aiken, SC 29808. 


\begin{tabular}{|c|c|c|c|}
\hline $\begin{array}{l}\text { Short Radius } \\
\text { Technology }\end{array}$ & $\begin{array}{l}\text { Modified } \\
\text { Petroleum } \\
\text { Technology }\end{array}$ & Utility Technology & $\begin{array}{l}\text { River Crossing } \\
\text { Technology }\end{array}$ \\
\hline \multicolumn{4}{|c|}{ Advantages } \\
\hline $\begin{array}{l}\text { Minimum Step-off } \\
\text { Distance }\end{array}$ & Short Step-off Distance & \begin{tabular}{|l} 
Minimum Drilling \\
Fluids
\end{tabular} & $\begin{array}{l}\text { Maximum Borehole } \\
\text { Control }\end{array}$ \\
\hline \multirow[t]{4}{*}{$\begin{array}{l}\text { Can Drill in } \\
\text { Consolidated Formations }\end{array}$} & $\begin{array}{l}\text { Can Drill in } \\
\text { Consolidated Formations }\end{array}$ & $\begin{array}{l}\text { Minimum Secondary } \\
\text { Waste }\end{array}$ & $\begin{array}{l}\text { Maximum Down-hole } \\
\text { Directional Control }\end{array}$ \\
\hline & & $\begin{array}{l}\text { Good Down-hole } \\
\text { Directional Control }\end{array}$ & $\begin{array}{l}\text { Maximum Flexibility in } \\
\text { Well Materials }\end{array}$ \\
\hline & & $\begin{array}{l}\text { Flexibility in Well } \\
\text { Materials }\end{array}$ & May Install Filter Pack \\
\hline & & Minimum Set-up Area & $\begin{array}{l}\text { Can Drill in } \\
\text { Consolidated Formations }\end{array}$ \\
\hline \multicolumn{4}{|c|}{ Disadvantages } \\
\hline Large Set-up Area & Large Set-up Area & \begin{tabular}{|l} 
Limited to \\
Unconsolidated \\
Formations
\end{tabular} & Large Set-up Area \\
\hline $\begin{array}{l}\text { High Volume of } \\
\text { Secondary Waste }\end{array}$ & $\begin{array}{l}\text { High Volume of } \\
\text { Secondary Waste }\end{array}$ & $\begin{array}{l}\text { Longer Step-off } \\
\text { Distance }\end{array}$ & $\begin{array}{l}\text { High Volume of } \\
\text { Secondary Waste }\end{array}$ \\
\hline $\begin{array}{l}\text { Doesn't Perform Well in } \\
\text { Unconsolidated } \\
\text { Formations }\end{array}$ & $\begin{array}{l}\text { Well Installation } \\
\text { Depends Heavily on } \\
\text { Drilling Fluid System }\end{array}$ & $\begin{array}{l}\text { Borehole Skin Damage } \\
\text { May be Extensive in } \\
\text { Clay Formations }\end{array}$ & $\begin{array}{l}\text { Longer Step-off } \\
\text { Distance }\end{array}$ \\
\hline \multicolumn{4}{|l|}{$\begin{array}{l}\text { Poor Down-hole } \\
\text { Directional Control }\end{array}$} \\
\hline $\begin{array}{l}\text { Lack of Borehole Control } \\
\text { During Well Installation }\end{array}$ & & & \\
\hline
\end{tabular}

Table 1: Advantages and disadvantages of different drilling technologies demonstrated. 


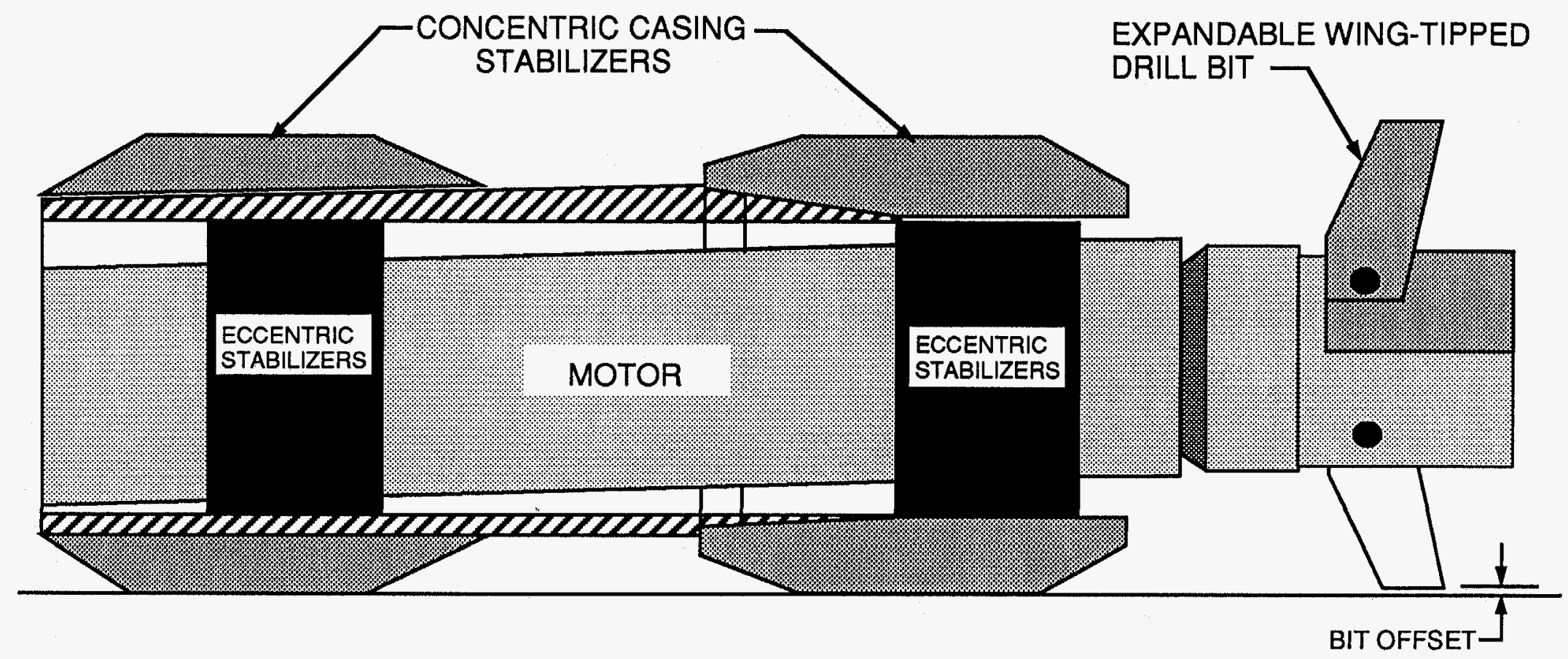

Figure 3: The downhole motor assembly used in the demonstration of the modified petroleum industry technology (original source, Eastman Christensen Environmental Systems). 


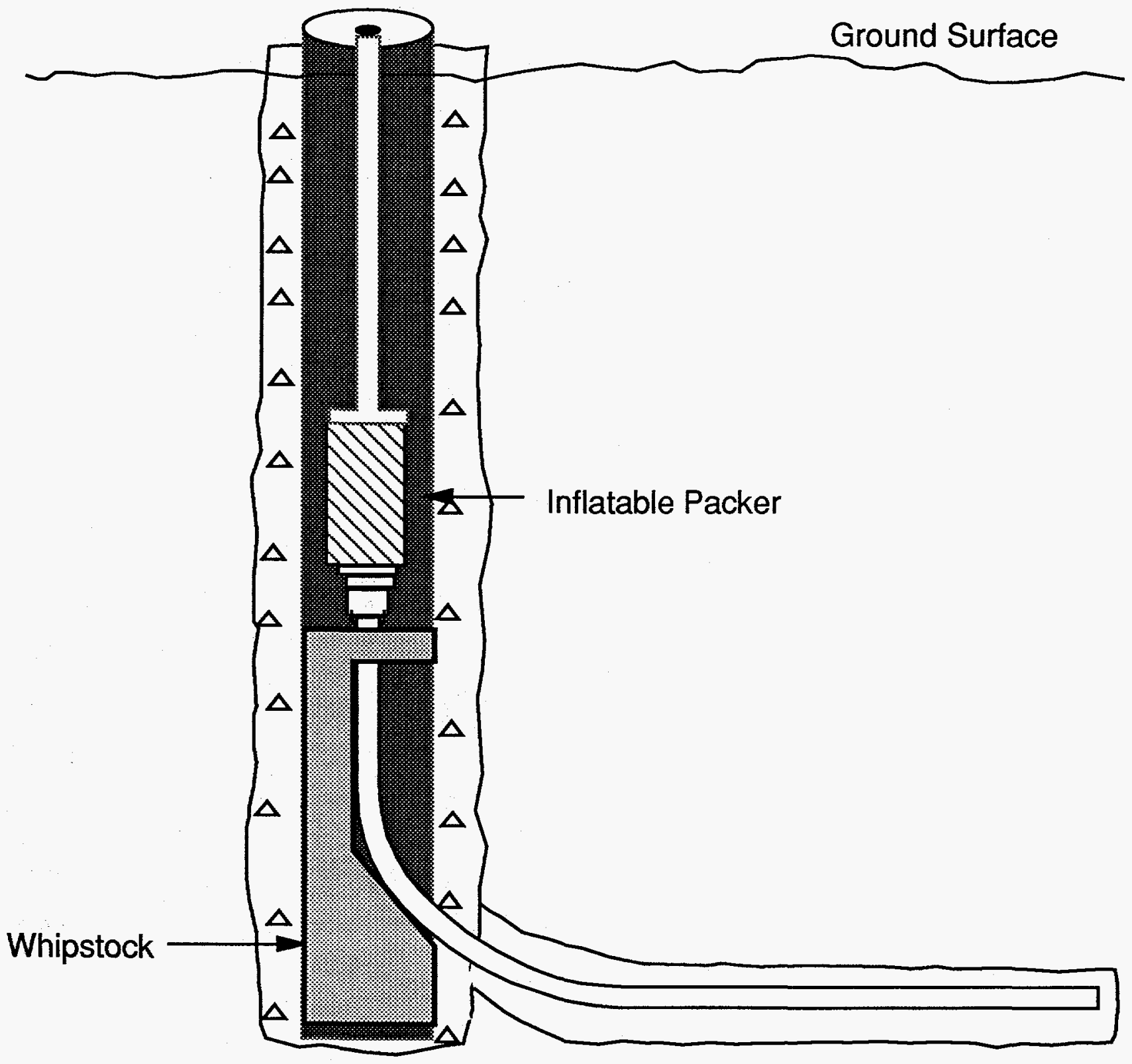

Figure 2: Short radius technology showing drill string deflecting off of whipstock. 
Biography: Kenneth H. Lombard, CM

Mr. Lombard is a Senior Environmental Engineer and Project Manager with Bechtel Savannah River Inc. He is currently assigned to Westinghouse Savannah River Co. where he works in the Environmental Sciences Section of the Savannah River Technology Center (SRTC). His work involves engineering support, logistics and project management for the research and development of new and innovative environmental remediation technologies for the clean-up of soils and ground water. Mr. Lombard is a published author and co-author of several technical papers and presentations in the field of bioremediation of chlorinated solvents and petroleum contaminated soils. Most recently, Mr. Lombard was lauded by SRS receiving the George Westinghouse Signature Award of Excellence for his role in the development of a nutrient injection system to support in situ methanotrophic bioremediation. 
Biography: Miles Denham, Ph.D.

Dr. Denham received a BA in Geology from Knox College, Galesburg, IL and an MS from the State University of New York at Stony Brook. In 1992 he received a Ph.D. from Texas A\&M University, where he specialized in aqueous geochemistry. Since 1992 he has been employed by Westinghouse Savannah River Company in the Environmental Sciences Section of the Savannah River Technology Center. Dr. Denham's work has focused on the research and development of horizontal wells for environmental remediation applications and geotechnical issues related to the clean-up of soils and ground water at the Savannah River Site. 